\title{
Similar community structure of biosynthetically active prokaryotes across a range of ecosystem trophic states
}

\author{
Krista Longnecker*, Delfina S. Homen, Evelyn B. Sherr, Barry F. Sherr \\ College of Oceanic and Atmospheric Sciences (COAS), Oregon State University, 104 COAS Admin. Bldg., Corvallis, \\ Oregon 97331-5503, USA
}

\begin{abstract}
Variability in both the abundance and phylogenetic diversity of biosynthetically active prokaryotes has implications for global carbon cycling. In the present study, our primary goal was to determine the extent of variability in phylogenetic diversity of biosynthetically active prokaryotes from 3 regions in the California Current System off the Oregon coast, ranging from eutrophic shelf to oligotrophic basin. Assimilation of ${ }^{3} \mathrm{H}$-leucine, as determined by microautoradiography, was combined with fluorescence in situ hybridization (MICROFISH) to identify biosynthetically active prokaryotes. Oligonucleotide probes targeted 2 domains (Bacteria and Archaea), and 4 groups within the Bacteria (Alphaproteobacteria, Betaproteobacteria, Gammaproteobacteria, and Cytophaga-like cells). We found that the Alphaproteobacteria and Cytophaga-like cells comprised the largest proportion of bacterial cells assimilating leucine. Alphaproteobacteria was the only group in which the abundance of active cells was significantly correlated to in situ phytoplankton stocks. Archaea were present in low numbers in most samples. However, in deep $(>250 \mathrm{~m})$ samples from the oligotrophic basin station, $43 \%$ of cells identified as Archaea were biosynthetically active. In general, we observed a similar change in the proportional abundance of cells assimilating leucine for all identified phylogenetic groups. Thus, at this phylogenetic level, our data set is evidence for tandem increase or decrease in biosynthetic activity by the whole prokaryotic community, rather than for shifts in activity by specific phylogenetic groups.
\end{abstract}

KEY WORDS: Marine prokaryotes $\cdot$ Metabolic activity $\cdot$ Microautoradiography $\cdot$ Diversity

\section{INTRODUCTION}

Insight into the extent of variability in cell-specific metabolic state is central to understanding the role of heterotrophic prokaryotes in the marine carbon cycle. The role of microorganisms is generally described in 2 different ways. In carbon cycling models, microorganisms can be considered as a single community (Anderson \& Ducklow 2001, Anderson \& Turley 2003), which is useful when the role of different phylogenetic or functional groups of microorganisms is unclear or unknown. Alternatively, as molecular tools have improved our understanding of the diversity of marine microorganisms (Giovannoni \& Rappé 2000), it has become possible to define differences in phylogenetic diversity of microorganisms within an ecosystem. However, whether or not the presence of microorganisms also indicates the presence of 'active' microorganisms is of particular interest, as the diversity of active cells can vary temporally and spatially within ecosystems, and between ecosystems. There are several different methods to identify active microorganisms; in this project active cells are those which have assimilated radioactively labeled leucine. Furthermore, the abundance of a prokaryotic group within an ecosystem may not be correlated with the abundance of active cells within that group (Cottrell \& Kirchman 2000). A central question in this work has been whether the 
phylogenetic compositions of active versus inactive bacterial cells were similar or different (Zubkov et al. 2002, Servais et al. 2003) in the upwelling system off Oregon, USA, in the spring of 2002.

The combination of microautoradiography with fluorescence in situ hybridization (referred to as MICROFISH in the present study; see for example Lee et al. 1999, Ouverney \& Fuhrman 1999, Cottrell \& Kirchman 2000) has been used to make quantitative estimates of the role of different phylogenetic groups within bacterioplankton communities. Previous research using MICROFISH has shown that the diversity of prokaryotes assimilating radioactively labeled materials varies with substrate (Cottrell \& Kirchman 2000) and ecological conditions (Cottrell \& Kirchman 2003, Teira et al. 2004). In addition, results from in situ and mesocosm studies have revealed variability in the diversity and abundance of bacterial phylotypes involved in sulfur cycling (Malmstrom et al. 2004a,b,

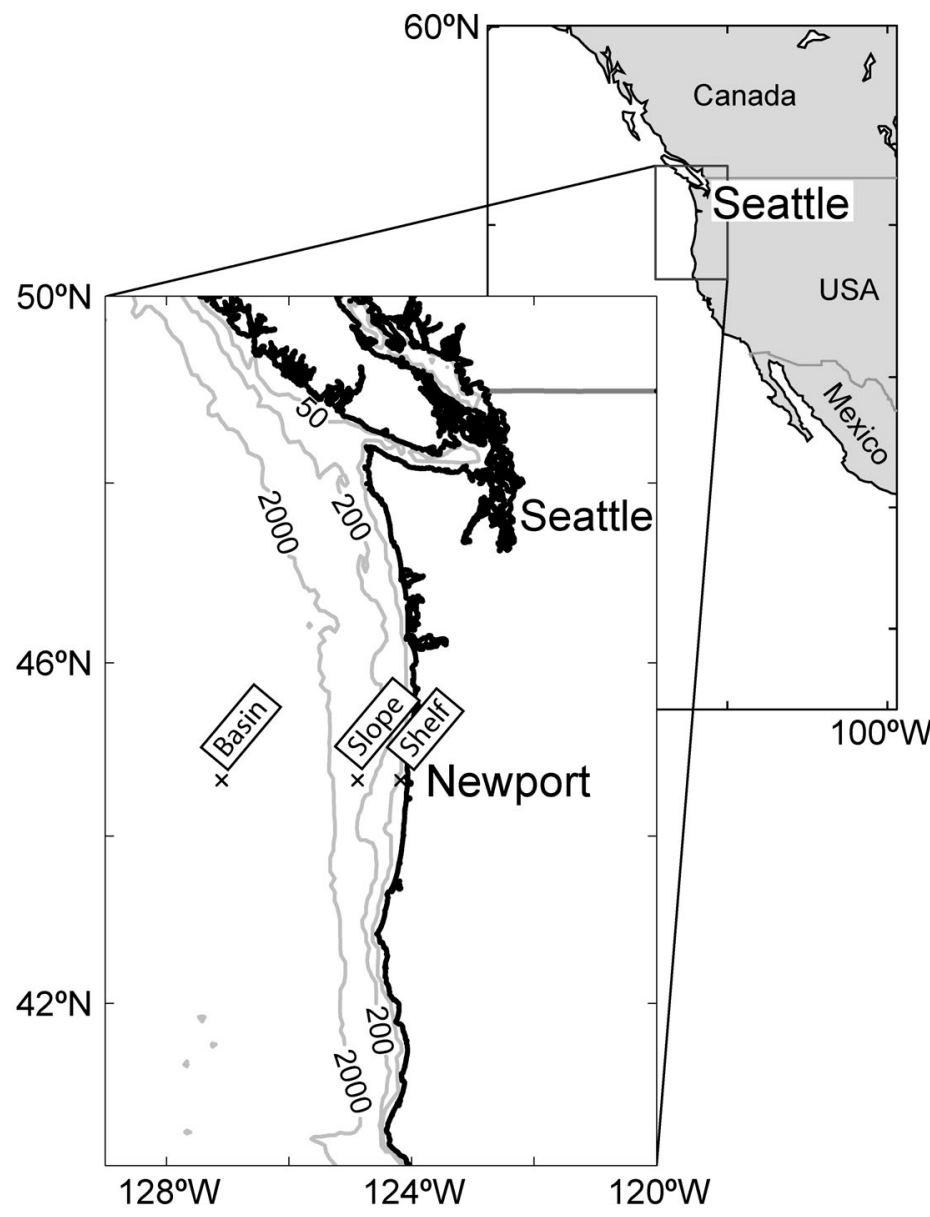

Fig. 1. Sampling area with contour lines indicating the 50, 200, and $2000 \mathrm{~m}$ isobaths. Multiple casts were conducted at each of the 3 stations $(x)$ : a shelf station (NH5), a slope station (NH35), and an offshore basin station above the abyssal plain (NH127)
Vila et al. 2004). To date, there has been no systematic examination of the abundance and diversity of marine bacterioplankton assimilating radioactively labeled amino acids across a range of trophic states in the open ocean.

The Oregon upwelling system provides a wide range of environmental conditions within relatively short geographic distances (Chavez et al. 2002, Huyer et al. 2002, Peterson et al. 2002) and, therefore, is an excellent system in which to examine the potential variability in the phylogenetic diversity of biosynthetically active prokaryotes. In the present study we found low variability in the diversity of active prokaryotes across the 3 ecosystems sampled. Furthermore, when conditions within the ecosystem changed, the activity of the entire prokaryotic community increased and no one group dominated the highly active cells.

\section{MATERIALS AND METHODS}

Sample collection and oceanographic parameters. Samples were collected during the spring of 2002 (April 26 to May 20), at the beginning of the upwelling season. Three stations were chosen along the Newport Hydrographic line extending westward from Newport, Oregon: a shelf station, $9 \mathrm{~km}$ from shore, bottom depth $60 \mathrm{~m}\left(\mathrm{NH} 5 ; 44.65^{\circ} \mathrm{N}, 124.18^{\circ} \mathrm{W}\right)$; a slope station, $65 \mathrm{~km}$ from shore, bottom depth $450 \mathrm{~m}\left(\mathrm{NH} 35 ; 44.65^{\circ} \mathrm{N}\right.$, $\left.124.88^{\circ} \mathrm{W}\right)$; and an offshore, basin station above the abyssal plain, $249 \mathrm{~km}$ from shore, bottom depth $2900 \mathrm{~m}$ (NH127; $44.65^{\circ} \mathrm{N}, 127.1^{\circ} \mathrm{W}$ ) (Fig. 1).

Seawater was collected at selected depths from 3 casts at both the slope and basin stations, and 5 casts at the shelf station, using General Oceanics 51 Niskin bottles mounted on a rosette equipped with a SeaBird SBE 911+ CTD, a SeaTech fluorometer, a Biospherical PAR sensor, and a SeaTech $25 \mathrm{~cm}$ transmissometer. From each cast, 1 sample was collected in the upper mixed layer, 1 from the pycnocline (where the greatest change in density was observed), and 1 from below the pycnocline. At the shelf station, water samples were collected to a maximum depth of $50 \mathrm{~m}$, which is $<10 \mathrm{~m}$ from the bottom. The maximum sampling depth at the slope station was $100 \mathrm{~m}$, while the maximum sampling depth at the basin station was $500 \mathrm{~m}$.

Chlorophyll concentration was used as a proxy for phytoplankton biomass. Discrete water samples were filtered through GF/F filters that were kept frozen at $-80^{\circ} \mathrm{C}$ for up to 1 mo before processing. Aliquots of $90 \%$ high-performance liquid chromatography (HPLC) grade acetone were added to the filters and allowed to extract overnight at $-20^{\circ} \mathrm{C}$. Chlorophyll a and pheopigment concentrations were determined using a Turner Designs 10-AU fluorometer (Strickland 
\& Parsons 1972). Samples for nutrient analysis were stored in $60 \mathrm{ml}$ high-density polyethylene bottles and frozen at sea $\left(-20^{\circ} \mathrm{C}\right)$. The analyses for phosphate, nitrate plus nitrite $(\mathrm{N}+\mathrm{N})$, nitrite, and silicic acid (silicate) were performed using a hybrid Technicon AutoAnalyzerII and Alpkem RFA300 system following protocols modified from Gordon et al. (1994). Nitrate concentrations were determined by subtracting nitrite from the $\mathrm{N}+\mathrm{N}$ value. The estimated precision for each element is: $\mathrm{PO}_{4}( \pm 0.008 \mu \mathrm{M}), \mathrm{N}+\mathrm{N}( \pm 0.15 \mu \mathrm{M}), \mathrm{NO}_{2}$ $( \pm 0.01 \mu \mathrm{M})$, and silicic acid $( \pm 0.3 \mu \mathrm{M})$.

The abundances of photoautotrophic and heterotrophic cells were determined based on flow cytometric counts using a Becton-Dickinson FACSCalibur flow cytometer. Water samples in $3 \mathrm{ml}$ aliquots were fixed with $0.2 \%$ w/v paraformaldehyde (final concentration), stored in the dark for at least 10 min at room temperature to harden cells, and quick-frozen in liquid nitrogen. Samples were then stored at $-80^{\circ} \mathrm{C}$ until sample processing on shore. A known concentration of fluorescent microspheres (Polysciences) was added to each sample to determine sample volume processed in the flow cytometer and, thus, cell abundance from cytometric counts. The concentration of the working stock of microspheres was pre-determined using Becton-Dickinson TrueCount beads. Cytograms of FL3 (red) fluorescence versus FL2 (orange) fluorescence were used to count Synechococcus and picoeukaryotes, while cytograms of side scatter versus FL3 fluorescence were used to count diatoms. The larger cells were more numerous in shelf waters, and were presumed to be diatoms, as microscopic inspection of epifluorescence preparations of samples taken from the high-chlorophyll a shelf waters showed that diatoms dominated the phytoplankton. Prochlorococcus cells were not observed in any of the samples. Heterotrophic cells were counted after staining with a $1 \times$ working stock of SYBR Green I (Molecular Probes) and $25 \mathrm{mM}$ potassium citrate for $15 \mathrm{~min}$ following a protocol modified from Marie et al. (1997). Heterotrophic cells were further separated based on nucleic acid content (green fluorescence) into high nucleic acid content (HNA) and low nucleic acid content (LNA) cells.

Incorporation rates of ${ }^{3} \mathrm{H}$-leucine by bacterioplankton present in whole-seawater samples were assayed following the protocol of Smith \& Azam (1992). Four $1.5 \mathrm{ml}$ aliquots of each water sample were pipetted into copolymer microcentrifuge tubes made by Eppendorf containing ${ }^{3} \mathrm{H}$-leucine (Perkin Elmer Life Science Products, specific activity $170 \mathrm{Ci} \mathrm{mmol}^{-1}$ ) to yield $20 \mathrm{nM}$ final concentration. One of the 4 aliquots served as a killed control, with $5 \%$ (final concentration) of trichloroacetic acid (TCA) immediately added to the tube. The aliquots were incubated for $1 \mathrm{~h}$ in the dark at the in situ water temperature $\left(5.1\right.$ to $\left.11.3^{\circ} \mathrm{C}\right)$. The sam- ples were then killed with 5\% TCA (final concentration) and stored frozen at $-20^{\circ} \mathrm{C}$. Samples were returned to shore and processed no more than $3 \mathrm{wk}$ after the sampling date. Prior experiments with radioactively labeled samples frozen for up to $1 \mathrm{mo}$ showed no difference in leucine-incorporation rates compared to unfrozen samples processed immediately (data not shown). Activity was determined using a Wallac 1141 liquid scintillation counter. The activity of the killed control was subtracted from the values for the 3 live aliquots.

Processing of samples for MICROFISH. We developed a modified procedure, optimized for the samples collected in this study, by combining microautoradiography and fluorescence in situ hybridization based on 3 existing protocols (Lee et al. 1999, Ouverney \& Fuhrman 1999, Cottrell \& Kirchman 2000). Whole-water samples were incubated immediately after collection with $40 \mathrm{nM}$ of ${ }^{3} \mathrm{H}$-leucine (specific activity $170 \mathrm{Ci} \mathrm{mmol}^{-1}$, Perkin Elmer Life Science Products) in the dark for $1 \mathrm{~h}$ in a $10^{\circ} \mathrm{C}$ water bath. Previous research revealed no significant differences in total leucine-incorporation rates using the higher leucine concentration and fixed temperature, as done here for the MICROFISH samples, compared to $20 \mathrm{nM}$ leucine and incubations at in situ water temperatures for obtaining whole-seawater leucine-incorporation rates (Longnecker et al. 2005). Samples were fixed with $0.2 \% \mathrm{w} / \mathrm{v}$ paraformaldehyde (final concentration), allowed to sit for at least $10 \mathrm{~min}$ in the dark, and then quick-frozen and stored in liquid nitrogen. After the return to shore, samples were transferred to a $-80^{\circ} \mathrm{C}$ freezer until processing.

Samples were filtered onto $0.2 \mu \mathrm{m}$ polycarbonate filters placed on top of a $0.45 \mu \mathrm{m}$ backing filter. The volume filtered averaged $6 \mathrm{ml}$, and ranged from 3 to $10 \mathrm{ml}$. The filters were cut using a razor blade into 8 sections and mounted onto glass slides. Seven different Cy3-labeled probes were used (Table 1), and all hybridizations were incubated overnight at $42^{\circ} \mathrm{C}$. All washes were performed at $48^{\circ} \mathrm{C}$, except for the EUB338 and NON338 probes, which were washed at $50^{\circ} \mathrm{C}$. The hybridization buffer contained $0.9 \mathrm{M} \mathrm{NaCl}$, $20 \mathrm{mM}$ Tris $(\mathrm{pH}=7.4), 0.01 \%$ SDS (sodium dodecyl sulfate), and formamide concentrations as in Table 1. Following the initial hybridization, slides were washed twice with $20 \mathrm{mM}$ Tris $(\mathrm{pH}=7.4), 0.01 \%$ SDS , and EDTA and $\mathrm{NaCl}$ concentrations as in Table 1. Washes were for $10 \mathrm{~min}$ each, followed by $10 \mathrm{~min}$ in $5 \mu \mathrm{g} \mathrm{ml}^{-1}$ DAPI at $4^{\circ} \mathrm{C}$, and $2 \mathrm{~min}$ in $4^{\circ} \mathrm{C}$ Milli-Q. The filters were allowed to dry before the next processing step. In the darkroom with a red light at least $1 \mathrm{~m}$ away, new slides were dipped into Kodak NTB-2 emulsion, and the filter pieces were placed face-down on the emulsion. The slides were incubated at $4^{\circ} \mathrm{C}$ for 12 to $14 \mathrm{~h}$. Following the incubation, the slides were developed for 4 min in 
Table 1. Hybridization and wash conditions used for oligonucleotide probes. Conditions were tested on nonradioactive samples from the Oregon upwelling system prior to use with the samples analyzed in this project

\begin{tabular}{|llcrcc|}
\hline Probe & Phylogenetic target & $\begin{array}{c}\text { Hybridization buffer: } \\
\text { formamide (\%) }\end{array}$ & NaCl (mM) & EDTA (mM) & Source \\
\hline EUB338 & Bacteria & 15 & 150 & 6 & Amann et al. (1990) \\
Arch915 & Archaea & 30 & 70 & 5 & Stahl \& Amann (1991) \\
Alf968 & Alphaproteobacteria & 35 & 80 & 5 & Glöckner et al. (1999) \\
Bet42a & Betaproteobacteria & 30 & 102 & 5 & Manz et al. (1992) \\
CFB319a & Cytophaga-like & 35 & 80 & 5 & Manz et al. (1996) \\
Gam42a & Gammaproteobacteria & 30 & 102 & 5 & Manz et al. (1992) \\
NON338 & Negative control & 15 & 150 & 6 & Wallner et al. (1993) \\
\end{tabular}

Kodak D-19 developer, stopped in Milli-Q water for $10 \mathrm{~s}$, placed in Kodak fixer for $5 \mathrm{~min}$, and washed in Milli-Q for $5 \mathrm{~min}$. When the slides were dry, the filter was removed from the slide, Citifluor was placed onto the area where the filter had been located, and a coverslip was attached to the glass slide using nail polish.

Slides were viewed on an Olympus BX-61 epifluorescence microscope using the filter sets appropriate for DAPI and Cy3 (indocarbocyanine)-labeled cells. Sufficient images were captured with a SensicamQE CCD camera (Cooke Corporation) to count at least 500 DAPIstained cells. Image Pro-Plus was used to filter the images and then threshold each image to define the location of the cells or silver grains. The masks generated by Image Pro-Plus were imported into Matlab, which was used to determine where the silver grains overlapped with the DAPI-stained and/or probe-stained cells. Cells that were touching silver grains were identified as cells that had assimilated ${ }^{3} \mathrm{H}$-leucine and were therefore biosynthetically active. Cells that were stained with both DAPI and the Cy3-labeled probes were identified as probe-positive cells. A total of 34 samples were processed, and hybridizations were performed with all 7 probes on each sample.

Calculations were made to determine the absolute and relative abundances of the different probe-stained populations and the absolute and relative abundances of probe-stained populations assimilating leucine. The proportion of each probe-stained population as a percent of the total population was calculated by dividing the number of probe-positive cells by the number of DAPIstained cells for each sample (percent abundance). The percent of each probe-positive group assimilating leucine was calculated by dividing the number of cells that were DAPI-stained, probe-positive, and assimilating leucine by the number of DAPI-stained and probepositive cells (percent assimilating). This latter calculation indicates what percent of each phylogenetic group was biosynthetically active. Standard deviations were calculated using a formula for the propagation of error (Bevington \& Robinson 2003) as follows:

$$
\frac{\Delta z}{z}=\sqrt{\frac{(\Delta x)^{2}}{x}+\frac{(\Delta y)^{2}}{y}}
$$

where $z$ is the percent abundance or the percent assimilating and is equal to $x$ divided by $y$, as described above. $\Delta x$ and $\Delta y$ are the standard deviations associated with $x$ and $y$, respectively. $\Delta z$ is the standard deviation calculated for $z$. Standard deviations were then converted to standard errors for each calculation.

Statistical analysis. Non-metric multidimensional scaling (NMS) (Kruskal 1964, Mather 1976) was used to analyze variability in the abundance and diversity of cells assimilating leucine in the present study. NMS is a multivariate statistical technique that can be used to examine the differences (or similarities) between samples by reducing the comparisons between samples from a multidimensional space to fewer dimensions, preferably 2 or 3. Differences between samples were calculated based on the abundance of probe-stained cells assimilating leucine obtained from MICROFISH. The differences were then presented graphically in a multidimensional space; samples that are close together in the ordination are more similar than samples located further apart. PC-ORD Ver. 4.19 (MjM Software Design) was used for the NMS with the Sorensen distance measure. Prior to running the NMS analysis, the abundance data were transformed using a square-root transformation to reduce the skewness and coefficient of variation of the data. A total of 40 runs were done with real data starting with random configurations, and Monte-Carlo simulations were conducted with 50 runs of randomized data, which were then compared to the output from the real data. The p-values were calculated as the proportion of randomized runs with stress less than or equal to the observed stress; stress is a measure of goodness-of-fit used in NMS. The dimensionality of the data set was assessed by comparing NMS runs with real data to the Monte-Carlo simulations. Additional axes were added if the addition of the axis resulted in a significant 
improvement over the randomized data (at $p \leq 0.05$ ) and the reduction in stress was $>5$. The proportion of variation represented by each axis was assessed by calculating the coefficient of determination $\left(\mathrm{r}^{2}\right)$ between distances in the ordination space and distance in the original space. For each probe, the average position of the group was calculated within the ordination using weighted averaging. The distances between the average positions are not calculated from a distance matrix but are averages of the abundances along each axis.

One advantage of NMS is the ability to compare differences between samples in conjunction with environmental variables. To do this, joint plots showing the relationship between the environmental data and the ordination scores were overlaid on the NMS plot; the angle and length of the line indicates the direction and strength of the relationship. The environmental data included: temperature, salinity, sigma-t, chlorophyll a and pheopigment concentrations, nutrient concentrations (nitrate, nitrite, phosphate, and silicate), and photoautotrophic (Synechococcus, diatoms, and picoeukaryotes) and heterotrophic (HNA and LNA) cell abundances.

Other statistical analyses were conducted in Matlab 7.0.1 (Mathworks). Analyses performed included Spearman rank correlations, Wilcoxon signed rank tests, and Kruskal-Wallis tests. All relationships were significant at the $\mathrm{p}<0.05$ level unless otherwise noted.

\section{RESULTS}

\section{Hydrographic data}

Hydrographic data revealed surface stratification with warmer water in the upper 5 to $50 \mathrm{~m}$ of all $3 \mathrm{sam}$ pling stations, although surface-water temperatures at the basin station were colder than at the shelf and slope stations (Table 2). Salinities ranged from 29.9 to 34.1. The freshest water was observed at the surface of the slope station, due to the influence of Columbia River outflow north of the sampling region. The final shelf and slope sampling casts were conducted $2 \mathrm{wk}$ after the first casts, and temperature and salinity data for the latter set of casts indicated the presence of warmer, saltier water at the surface of both stations compared to the initial sampling casts. The highest chlorophyll concentrations were close to shore at the shelf, and lower values were at the slope and basin stations (Table 2). Bacterial leucine incorporation was also highest in the shelf region (Table 2). In the warmer, saltier water observed in the later part of the cruise, bacterial leucine incorporation increased at the shelf station $>3$-fold compared to values measured in the first $2 \mathrm{wk}$ of the cruise (individual data not shown).

\section{Abundances of total and biosynthetically active cells}

Digital images from the CCD camera were overlapped in Matlab to determine which cells were labeled with both the Cy3 stain and DAPI. On average, $47 \%$ (40 to $54 \%$, 95\% confidence interval) of DAPIstained cells were stained with the EUB338 probe. Therefore, $53 \%$ of DAPI-stained cells were not labeled by the EUB338 probe. Mean counts from the NON probe represented $<5 \%$ of DAPI counts. The sum of the counts from the 4 bacterial probes (Alf968, Bet42a, CFB319a, and Gam42a) was not significantly different from the EUB338 counts ( $p=0.67$, signed rank test).

Cells that assimilated leucine were considered biosynthetically active cells. The abundance of biosynthetically active cells for each probe was determined by counting the number of cells touching or overlapping silver grain(s) after development of the emulsion.

Table 2. Sampling regions and selected environmental parameters. Values are given as means (range of values in parentheses); n.d.: chlorophyll levels were below detection

\begin{tabular}{|c|c|c|c|c|c|c|}
\hline & $\begin{array}{l}\text { Depth } \\
\text { (m) }\end{array}$ & $\begin{array}{l}\text { Chlorophyll a } \\
\qquad\left(\mu \mathrm{g}^{-1}\right)\end{array}$ & $\begin{array}{l}\text { Nitrate } \\
(\mu \mathrm{M})\end{array}$ & $\begin{array}{l}\text { Temperature } \\
\left({ }^{\circ} \mathrm{C}\right)\end{array}$ & $\begin{array}{c}\text { Heterotrophic cell } \\
\text { abundance }\left(\times 10^{6} \mathrm{ml}^{-1}\right)\end{array}$ & $\begin{array}{c}\text { Bacterial leucine } \\
\text { incorporation }\left(\mathrm{pM} \mathrm{h}^{-1}\right)\end{array}$ \\
\hline \multirow[t]{3}{*}{ Shelf } & $2-8$ & $18.3(10.8-40.4)$ & $5.3(0.1-15.8)$ & $9.5(8.7-10.6)$ & $1.2(0.9-1.4)$ & $245(102-443)$ \\
\hline & $11-25$ & $7.1(0.4-33)$ & $19.9(2.8-28.7)$ & $8.5(8.2-9.8)$ & $1(0.6-2.2)$ & $110(6-515)$ \\
\hline & $32-50$ & $0.7(0.4-1)$ & $32(30.1-33.8)$ & $7.6(7.2-7.9)$ & $0.6(0.5-0.9)$ & $12(6-20)$ \\
\hline \multirow[t]{3}{*}{ Slope } & $3-10$ & $0.6(0.4-0.7)$ & $0(0-0)$ & $11(10.6-11.3)$ & $1.1(0.9-1.3)$ & $73(61-85)$ \\
\hline & $17-30$ & $2.2(0.6-3.5)$ & $0.3(0.1-0.6)$ & $9.9(9.5-10.2)$ & $1.5(1.2-1.7)$ & $41(38-43)$ \\
\hline & $40-100$ & $0.8(0.3-1.5)$ & $10.8(4.6-21.2)$ & $8.8(8.4-9.4)$ & $0.8(0.3-1.2)$ & $3^{a}$ \\
\hline \multirow[t]{3}{*}{ Basin } & $20-50$ & $0.8(0.7-1)$ & $5.1(5-5.2)$ & $9.3(9.2-9.3)$ & $1.7(1.2-2.5)$ & $9(8-11)$ \\
\hline & $100-150$ & n.d. & $21.3(14.5-28.9)$ & $8(7.4-8.5)$ & $0.4(0.3-0.4)$ & $2(1-2)$ \\
\hline & $300-350$ & n.d. & $36.9(35.9-38.2)$ & $6.3(5.9-6.7)$ & $0.2(0.2-0.2)$ & $1(1-1)$ \\
\hline
\end{tabular}




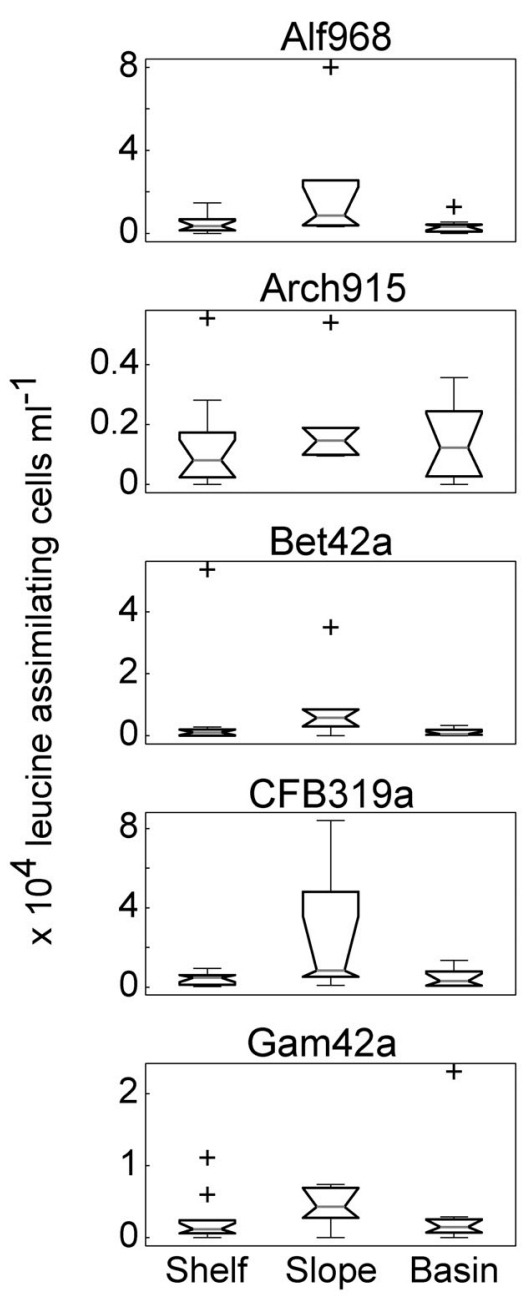

Fig. 2. Abundance of leucine-assimilating prokaryotes in each group. Data only include samples collected in the upper $50 \mathrm{~m}$ of the water column. The box represents the inter-quartile range (IQR) of the data. The bars extend to include data within 1.5 IQRs of the box. Outliers (+) are defined as abundances $>1.5$ IQRs from the box

The number of probe-stained cells assimilating leucine was lowest for the Arch915-stained cells (mean: $0.42 \times$ $10^{4}$ cells $\mathrm{ml}^{-1}$; $95 \%$ confidence interval: 0.05 to $0.78 \times$ $\left.10^{4}\right)$ and highest for CFB319a-stained cells $\left(1.3 \times 10^{4}\right.$ cells $\mathrm{ml}^{-1}$; 0.7 to $2.0 \times 10^{4}$ ) and Alf968-stained cells $\left(1.1 \times 10^{4}\right.$ cells $\mathrm{ml}^{-1} ; 0.5$ to $\left.1.7 \times 10^{4}\right)$. The only significant difference between stations in the abundance of biosynthetically active cells was for cells hybridized to the Alf968 probe; the abundance of Alf968-stained cells assimilating leucine was significantly higher at the slope station compared to the shelf station (Kruskal-Wallis test, $\mathrm{p}=0.016$, followed by a multiple comparison of mean ranks). No other comparisons between stations for the Alf968 data were significantly different, and there were no other significant betweenstation differences.
As samples were taken over a wide range of depths, these analyses were repeated to only consider either the upper $50 \mathrm{~m}$ or the upper $100 \mathrm{~m}$ of the water column. Considering only the surface samples, there were no significant differences in the abundance of leucine-assimilating cells in any of the probe-stained groups (Kruskal-Wallis test, all p > 0.05). The abundance of all probe-stained cells from samples collected in the upper $50 \mathrm{~m}$ of the water column did vary between stations; however, the abundance of leucineassimilating cells did not vary between sampling stations (Fig. 2).

\section{NMS results and their interpretation}

NMS was used in this study to compare samples from all 3 stations and the different sampling depths. The first step in this analysis was to compare samples based on the similarities in the abundance of leucineassimilating prokaryotes. The differences between samples were calculated using the Sorensen distance measure. This allowed us to consider the abundances of all groups (Alf968, Arch915, Bet42a, CFB319a, and Gam42a), yet reducing the comparisons between samples such that the difference between any 2 samples was a single number. NMS was then used to visualize the differences between samples by representing each sample as a single point in a single graphic. After this graphic has been generated, the environmental data associated with each sample can be considered; this allowed us to examine the environmental parameters associated with each sample and thus to link differences in the ecosystem with differences in the prokaryotic community structure.

The resulting patterns from the NMS in the abundance of biosynthetically active cells identified by MICROFISH are shown in Fig. 3. Each point within the 2-dimensional ordination shown in Fig. 3 is a different sample; the distances between the points represent the relative dissimilarity between samples, whereby larger distances represent greater differences. The final solution was the result of 112 iterations, with a final stress of 15.4 and a final instability of $1.0 \times 10^{-5}$. The cumulative proportion of variation explained by the final 2-dimensional solution was 0.87 , with 0.13 and 0.74 on Axis 1 and Axis 2, respectively. The ordination was calculated with the Sorensen distance measure, which considered changes in the abundance of biosynthetically active cells for each of the different probes. Attempts to consider changes in the proportion of biosynthetically active cells did not result in a stable NMS solution. Therefore, the differences in the proportion of cells stained with each probe were small between stations and sampling depths. 
The NMS revealed no clear division of samples based on region. However, shelf- and slope-station samples collected in the later part of the cruise were clustered at the upper end of Axis 2. These samples also formed a separate group when the differences between samples were compared using cluster analysis with the Sorensen distance measure (data not shown). In the NMS ordination, the samples were primarily separated based on density (sigma-t), with deeper samples clustering at the bottom of Axis 2 and shallower samples at the upper end of Axis 2 (Fig. 3). Although the NMS was

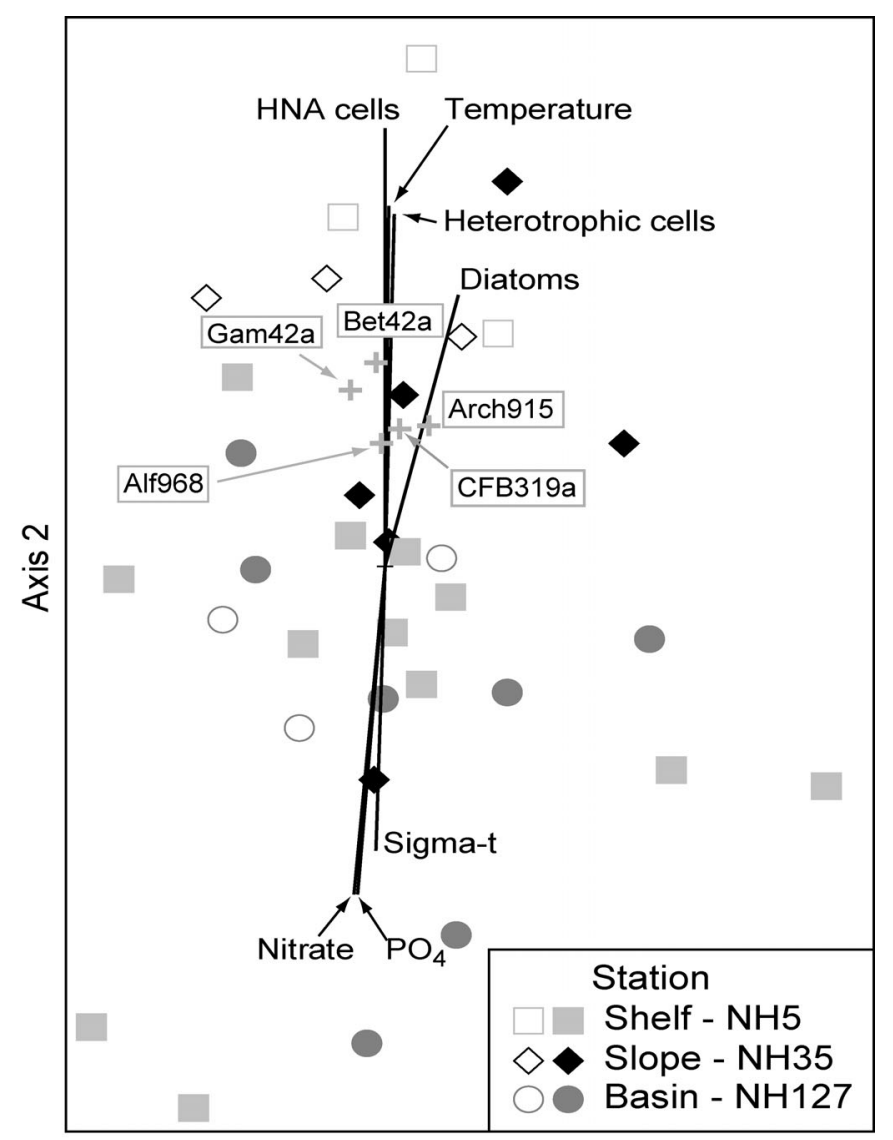

Axis 1

Fig. 3. Non-metric multidimensional scaling (NMS) analysis showing the differences between samples based on the abundance of probe-stained cells touching silver grains, i.e. probestained cells which have assimilated ${ }^{3} \mathrm{H}$-leucine. Sampling occurred over a $4 \mathrm{wk}$ period (filled symbols: samples from the first $2 \mathrm{wk}$; open symbols: samples from the second $2 \mathrm{wk})$. The joint plots highlighting the correlations with environmental data are overlaid on the ordination results and are labeled for each variable; only environmental data with correlations $>0.2$ on either Axis 1 or Axis 2 are shown in the figure. The weighted average position for each probe within the ordination is given by $(+)$ and labeled with the probe name. Each point within the figure is a single sample. Points that are closer together are more similar, based on the pattern of leucineassimilating cells within the 5 prokaryotic groups; points that are located further apart display greater differences calculated based on the abundance of biosynthetically active cells, environmental data from the same samples can be considered along with abundance data. Joint plots overlaid on the ordination were used to show correlations between environmental data and ordination scores. Highlighting depth-related differences, samples with higher nutrient concentrations and salinities were negatively correlated with Axis 2, while surface samples with higher cell counts and temperatures were positively correlated with Axis 2.

The NMS analysis revealed low variability in the diversity of biosynthetically active cells in 2 ways. First, the abundance of biosynthetically active cells was positively correlated with Axis 2 for all the probes (data not shown), with the highest abundances obtained for the samples collected in the later part of the cruise. The mean abundance of leucine-assimilating cells more than doubled during the later part of the cruise at the shelf and slope stations (Fig. 4). In addition, the weighted average positions of the probe-stained groups within the ordination were all clustered together in the middle of the ordination (Fig. 3).

\section{Relative abundance of leucine-assimilating prokaryotes}

The proportions of prokaryotic cells assimilating leucine in each identified phylogenetic group were calculated and compared to their relative abundance within the community (Fig. 5). There was more variability in the percent of biosynthetically active cells than in the percent abundance of prokaryotic cells in each group. The maximum percent abundance observed was $70 \%$, while the percent of biosynthetically active cells within a group could be up to $100 \%$ (Fig. 5), indicating that $100 \%$ of the cells within a phylogenetic group were assimilating leucine. The percent abundance of Bet42a-stained cells was significantly correlated to the percent of biosynthetically active Bet42a-stained cells (Spearman rank correlation, $\mathrm{r}=0.39, \mathrm{p}=0.021$ ); this comparison was not significant for any other group of probe-stained cells.

The shelf station samples exhibited the highest range of biosynthetically active cells compared to the samples from the slope and basin stations (Fig. 5). At the shelf station, the highest median values were obtained for the Bet42a- and CFB319a-stained cells. At the slope station, the biosynthetically active community was dominated by Alf968-stained cells, with Bet42a- and CFB319a-stained cells making a lesser contribution. In general, a lower percentage of cells were biosynthetically active at the basin station, with CFB319a-stained cells having the highest median percentage of biosynthetically active cells. 


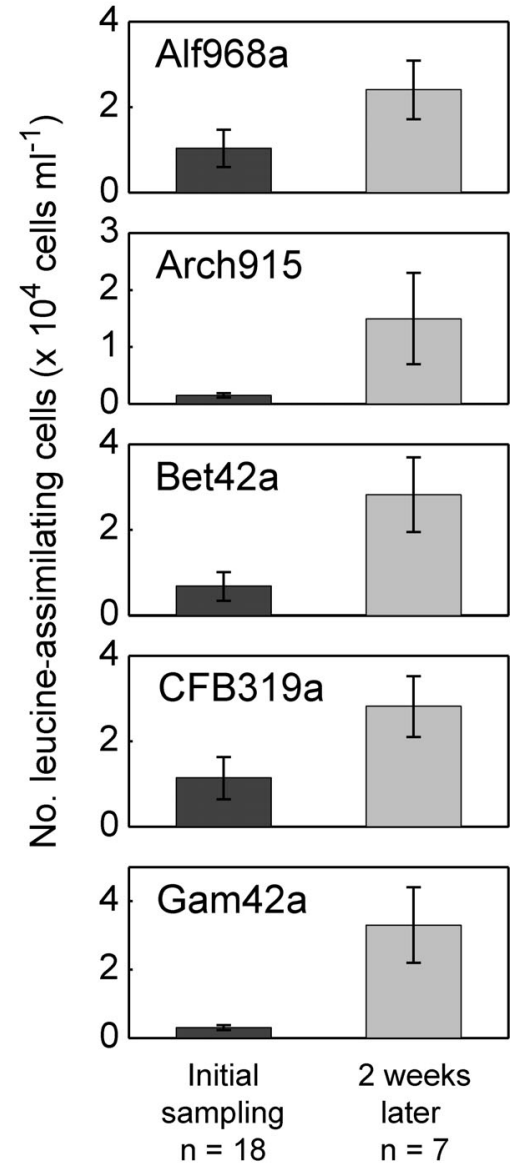

Fig. 4. Change in the abundance of prokaryotic cells assimilating leucine in the first part of the cruise compared to samples collected 2 wk later. Values are mean abundances for each part of the cruise, error bars are SE. Data from the basin station are not included as there was no change in the abundance of leucine-assimilating cells between the first and second part of the cruise
Cells stained with the Arch915 archaeal probe exhibited a different pattern of activity at the basin station compared to the shelf and slope stations closer to the shore. At the slope and shelf stations, there was no relation between the relative abundance of Arch915-stained cells and the percentage of biosynthetically active archaeal cells. However, at the basin station in samples from water depths $>250 \mathrm{~m}$, the Arch915-stained cells were a small proportion of the microbial community (mean abundance of $4.1 \%$ ), but a large proportion of the Arch915-stained cells were assimilating leucine (mean of $43 \%$ ) (Fig. 6).

\section{MICROFISH data examined in conjunction with environmental parameters}

The abundance of cells scored as biosynthetically active was compared to the environmental parameters measured concurrently with the water samples used for the MICROFISH analysis. Comparisons were made between the environmental parameters and the abundance of probe-positive cells and the abundance of biosynthetically active probe-positive cells. Significant negative correlations were observed between sigma-t and (1) the abundance of probe-stained cells and (2) the abundance of biosynthetically active probestained cells for the following probes: Alf968, Bet42a, CFB319a, and Gam42a (Spearman rank correlations, p $<0.05$; Table 3). Significant positive correlations were observed between the abundance of probestained cells for the Alf968, Bet42a, and CFB319a probes and the 3 different groups of phytoplankton that were counted with the flow cytometer (Synechococcus, diatoms, and picoeukaryotes; Spearman
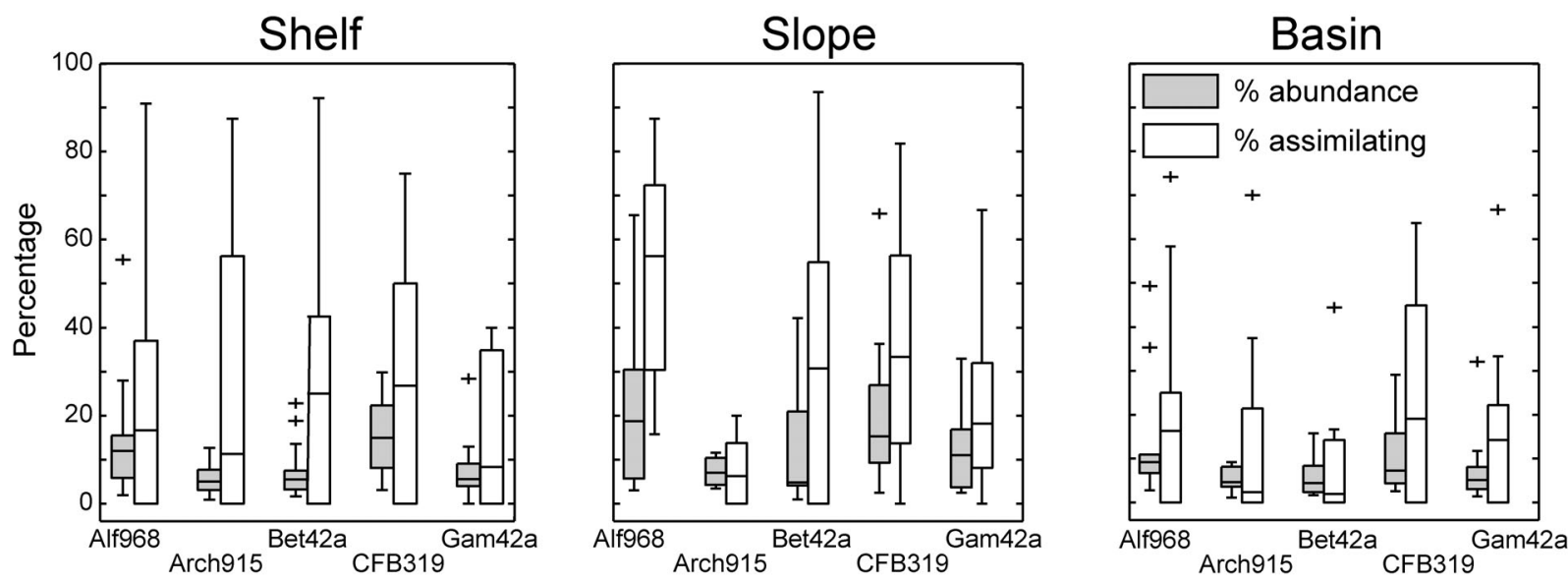

Fig. 5. Relative abundance of each group and percent of cells assimilating leucine for the group. Boxes represent the interquartile range (IQR) of the percentage data; bars extend to include data within 1.5 IQRs of the box. Outliers (+) are defined as percentages $>1.5$ IQRs from the box 
rank correlations, $\mathrm{p}<0.05$; Table 3). However, the abundance of probe-stained cells assimilating leucine was significantly correlated to the abundances of Synechococcus, diatoms, and picoeukaryotes only for the Alf968-stained cells.

\section{DISCUSSION}

A common observation in marine ecosystems is that the activity of marine bacterioplankton varies more than their abundance (Cole et al. 1988, Ducklow 2000,

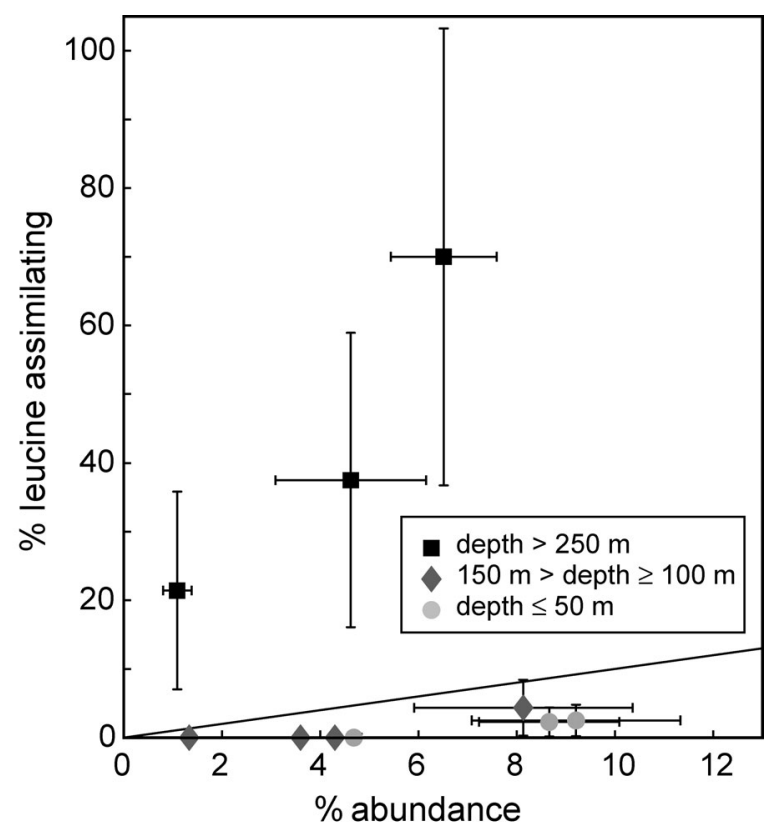

Fig. 6. Proportion of Archaea assimilating leucine at the basin station ( $\mathrm{n}=10$; for range of sampling depths, see key). Error bars are SE calculated with the propagation of error formula given in the 'Materials and methods' section

Table 3. Spearman rank correlations between environmental parameters and (1) abundance of probe-stained cells and (2) abundance of biosynthetically active probe-stained cells. Values are Spearman's rho ( $p$-values in parentheses) n.s.: correlation was not significant

\begin{tabular}{|c|c|c|c|c|}
\hline Group & Sigma-t & Synechococcus & Diatoms & Picoeukaryotes \\
\hline \multicolumn{5}{|c|}{ Abundance of probe-stained cells } \\
\hline Alf968 & $-0.471(0.004)$ & $0.489(0.003)$ & $0.435(0.009)$ & $0.460(0.005)$ \\
\hline Bet42a & $-0.371(0.028)$ & $0.425(0.011)$ & $0.367(0.030)$ & $0.511(0.002)$ \\
\hline CFB319a & $-0.451(0.007)$ & $0.384(0.023)$ & $0.395(0.019)$ & $0.457(0.006)$ \\
\hline Gam42a & $-0.356(0.036)$ & n.s. & n.s. & n.s. \\
\hline \multicolumn{5}{|c|}{ Abundance of biosynthetically active probe-stained cells } \\
\hline Alf968 & $-0.466(0.005)$ & $0.444(0.008)$ & $0.357(0.035)$ & $0.430(0.010)$ \\
\hline Bet42a & $-0.404(0.016)$ & n.s. & n.s. & n.s. \\
\hline CFB319a & $-0.387(0.022)$ & n.s. & n.s. & n.s. \\
\hline Gam42a & $-0.400(0.017)$ & n.s. & n.s. & n.s. \\
\hline
\end{tabular}

Sherr et al. 2001). Possible explanations for high variability in bacterial cell-specific activity include topdown or bottom-up controls on microbial activity and abundance. This study examined the role of bottom-up control on microbial activity by utilizing in situ differences in 3 oceanic ecosystems within the Oregon upwelling system: a eutrophic shelf region, a mesotrophic slope region, and an oligotrophic basin region $250 \mathrm{~km}$ from the shore. Our initial hypothesis was that there would be differences in abundance and phylogenetic diversity of cells actively assimilating leucine across the 3 ecosystems. This hypothesis was derived from research in the Delaware estuary, which has revealed that the diversity of bacterial cells assimilating leucine and thymidine was not constant within the estuary. Instead, different phylogenetic groups, at the same taxonomic levels as those examined in this study, were biosynthetically active at different salinities within the estuary (Cottrell \& Kirchman 2003, 2004).

Our data indicated that the diversity of biosynthetically active cells across the range of marine ecosystems sampled was not regionally separated, although there were changes in the abundance of biosynthetically active cells between sampling stations and with depth. There was a significant difference in the abundance of biosynthetically active Alphaproteobacteria between the slope and basin stations, but this did not apply to Betaproteobacteria, Gammaproteobacteria, Archaea, and Cytophaga-like cells. However, the low p-value $(p=0.016)$ for the observed difference in Alphaproteobacteria between the slope and basin stations indicated differences in abundance were not large. The observed within-station variability in the abundance and diversity of leucine-assimilating cells may be linked to small-scale differences in the activity of marine bacterioplankton (Seymour et al. 2000, 2004).

This lack of significant differences in the abundance of biosynthetically active cells among stations combined with results from the NMS analysis indicated that changes in the abundance of biosynthetically active cells occurred for all groups simultaneously and no one group increased or decreased its abundance of biosynthetically active cells to the exclusion of other groups. Therefore, although there were changes in both the physical parameters and the photoautotrophic community, with respect to the phylogenetically defined groups identified in this study, different components of the heterotrophic community did not respond differentially. Given the high diversity of marine prokaryotes (Giovannoni \& Rappé 2000), the 
lack of phylogenetic difference among biosynthetically active prokaryotes observed in the present study was unexpected and does not support the idea that phylogenetic variability in marine prokaryotic communities can be explained in part by variability in metabolic response. Furthermore, these data emphasize that the abundance of prokaryotes within an ecosystem may not reveal sufficient information to determine the abundance of prokaryotes actively involved in biogeochemical processes.

Cytophaga-like organisms comprise up to $30 \%$ of marine prokaryotic communities (Glöckner et al. 1999, Eilers et al. 2000, Cottrell \& Kirchman 2003), and their involvement in consumption of high molecular weight organic matter has been noted within estuarine systems (Cottrell \& Kirchman 2000). At all 3 stations sampled during the present study, the percentage of $\mathrm{Cy}$ tophaga-like cells assimilating leucine was higher than the percent abundance of Cytophaga-like cells in more than half of the samples. In the Delaware estuary, Cytophaga-like cells were more involved in leucine and thymidine uptake in fresher regions of the estuary (Cottrell \& Kirchman 2003, 2004), although there was an increase in the percent of Cytophaga-like cells assimilating leucine at the seaward-most station during 1 sampling period (Cottrell \& Kirchman 2004). The presence of Cytophaga-like cells in the potentially more active bacterioplankton containing high nucleic acid (Longnecker et al. 2005), combined with indications from the present study that they incorporate leucine proportionally more than indicated by their relative abundance, highlights the important role they may play in organic matter utilization in marine systems.

Alphaproteobacteria are a large component of the marine prokaryotic community (Eilers et al. 2000, Giovannoni \& Rappé 2000, Morris et al. 2002, Venter et al. 2004) and were an important component of the biosynthetically active community during our study. Furthermore, while abundances of Alphaproteobacteria, Betaproteobacteria, and Cytophaga-like cells were all correlated to phytoplankton abundances, only the abundance of biosynthetically active Alphaproteobacteria was also significantly correlated to phytoplankton abundances. Links between Alphaproteobacteria and phytoplankton have also been demonstrated in the Atlantic Ocean, where Alphaproteobacteria dominate the assimilation of dimethylsulfoniopropionate (DMSP), an algal-derived compound (Malmstrom et al. $2004 a, b)$. Given the additional observation that the proportion of active Alphaproteobacteria increased with salinity in the Delaware estuary (Cottrell \& Kirchman 2003), Alphaproteobacteria may be especially suited to the marine environment.

Our data provide further evidence that Archaea found in the open ocean are biosynthetically active.
For a number of samples in the Oregon upwelling system, $>40 \%$ of the cells identified as Archaea had assimilated leucine. While no clear pattern was evident for the shelf-station samples, in the basin-station samples, higher proportions of active Archaea were observed at water depths $>250 \mathrm{~m}$. Archaea have been shown to make up about $40 \%$ of the cells detected below $1000 \mathrm{~m}$ (Karner et al. 2001). Furthermore, several recent studies have reported the increased abundance of biosynthetically active archaeal cells in deep marine waters (200 to $3000 \mathrm{~m}$ ) (Ouverney \& Fuhrman 2000, Teira et al. 2004, Herndl et al. 2005). Neither the relative abundance of Archaea, nor the abundance of biosynthetically active Archaea were correlated with the environmental parameters measured in this study, suggesting that some other factor, which we did not measure, causes variability in the abundance of biosynthetically active Archaea. Changes in the composition and quantity of organic material with depth (Benner et al. 1992, 1997) are likely to affect the availability of this material to the prokaryotic community (Carlson 2002). Archaea may be at a competitive disadvantage compared to Bacteria in the upper mixed layer, though this is an untested hypothesis.

Despite a strong trophic gradient across the transect, we did not find major changes in the overall diversity of biosynthetically active cells, as have been observed in other ecosystems (Lee et al. 1999, Ouverney \& Fuhrman 2000, Cottrell \& Kirchman 2003, 2004). Use of 6 different probes, including 2 that were designed to separate prokaryotes by domain, did not show significant variability in the proportional abundances of biosynthetically active prokaryotes between sampling stations. If there had been regional differentiation, the sample points within the NMS would have formed 3 distinct clusters based on sample station, which was not the case. The warmer and saltier water mass that appeared in the later part of the cruise was accompanied by increased rates of bacterial leucine incorporation. However, in this water mass, all of the groups studied exhibited similar increases in the abundance of biosynthetically active cells. While the use of MICROFISH did allow us to quantify the abundance of biosynthetically active cells, it could not fully explain previously observed small-scale variability in diversity (Long \& Azam 2001). Utilization of probes designed to target more specific phylogenetic groups (i.e. genusor family-level probes) may be required to resolve variability in biosynthetic activity between marine prokaryotes.

Our study adds to the understanding that Archaea play a biogeochemically significant role below the euphotic zone (Karner et al. 2001, Herndl et al. 2005) and provides further evidence for a link between the relative activity of bacterial phylotypes in the Alpha- 
proteobacteria and the in situ phytoplankton community (Malmstrom et al. 2004a,b). However, whether the low variability in the relative proportions of high-level phylogenetic groups contributing to the community of biosynthetically active bacterioplankton cells is a general feature of open-ocean habitats will require further research.

Acknowledgements. We thank M. Lichtenberg, R. Condon, J. Fleischbein, and J. Jennings for technical assistance; the captain, crew, and marine technicians of the RV 'Wecoma' for assistance at sea; and the other cruise participants for thoughtful discussions during and after the cruise. We are grateful to R. Morris for providing tips on FISH, and M. Cottrell for initial guidance on image analysis. The comments of the anonymous reviewers were appreciated, as they helped clarify the presentation of the results. This research was funded by the National Science Foundation (Ocean Sciences), NSF OCE-0002236 and OCE-0240785 to B.F.S. and E.B.S.

\section{LITERATURE CITED}

Amann RI, Binder BJ, Olson RJ, Chisholm SW, Devereux R, Stahl DA (1990) Combination of 16S rRNA-targeted oligonucleotide probes with flow cytometry for analyzing mixed microbial populations. Appl Environ Microbiol 56: 1919-1925

Anderson TR, Ducklow HW (2001) Microbial loop carbon cycling in ocean environments studied using a simple steady-state model. Aquat Microb Ecol 26:37-49

Anderson TR, Turley CM (2003) Low bacterial growth efficiency in the oligotrophic eastern Mediterranean Sea: a modelling analysis. J Plankton Res 25:1011-1019

Benner R, Pakulski JD, McCarthy M, Hedges JI, Hatcher PG (1992) Bulk chemical characteristics of dissolved organic matter in the ocean. Science 255:1561-1564

Benner R, Biddanda B, Black B, McCarthy M (1997) Abundance, size distribution, and stable carbon and nitrogen isotopic compositions of marine organic matter isolated by tangential-flow ultrafiltrations. Mar Chem 57:243-263

Bevington PR, Robinson DK (2003) Data reduction and error analysis for the physical sciences. McGraw Hill, San Francisco, CA

Carlson CA (2002) Production and removal processes. In: Hansell DA, Carlson CA (eds) Biogeochemistry of marine dissolved organic matter. Academic Press, New York, p 91-151

Chavez FP, Pennington JT, Castro CG, Ryan JP and 6 others (2002) Biological and chemical consequences of the 1997-1998 El Niño in central California waters. Prog Oceanogr 54:205-232

Cole JJ, Findlay S, Pace ML (1988) Bacterial production in fresh and saltwater ecosystems: a cross-system overview. Mar Ecol Prog Ser 43:1-10

Cottrell MT, Kirchman DL (2000) Natural assemblages of marine Proteobacteria and members of the Cytophaga-Flavobacter cluster consuming low- and highmolecular-weight dissolved organic matter. Appl Environ Microbiol 66:1692-1697

Cottrell MT, Kirchman DL (2003) Contribution of major bacterial groups to bacterial biomass production (thymidine and leucine incorporation) in the Delaware estuary. Limnol Oceanogr 48:168-178

Cottrell MT, Kirchman DL (2004) Single-cell analysis of bac- terial growth, cell size and community structure in the Delaware estuary. Aquat Microb Ecol 34:139-149

Ducklow H (2000) Bacterial production and biomass in the oceans. In: Kirchman DL (ed) Microbial ecology of the oceans. Wiley-Liss, New York, p 85-120

Eilers H, Pernthaler J, Glöckner FO, Amann R (2000) Culturability and in situ abundance of pelagic bacteria from the North Sea. Appl Environ Microbiol 66:3044-3051

Giovannoni SJ, Rappé M (2000) Evolution, diversity, and molecular ecology of marine prokaryotes. In: Kirchman DL (ed) Microbial ecology of the oceans. Wiley-Liss, New York, p 47-84

Glöckner FO, Fuchs BM, Amann R (1999) Bacterioplankton compositions of lakes and oceans: a first comparison based on fluorescence in situ hybridization. Appl Environ Microbiol 65:3721-3726

Gordon LI, Jennings JC, Ross AA, Krest JM (1994) A suggested protocol for continuous flow automated analysis of seawater nutrients (phosphate, nitrate, nitrite and silicic acid) in the WOCE hydrographic program and the Joint Global Ocean Fluxes Study. In: WOCE operations manual. WOCE Report No. 68/91, Revision 1, Woods Hole Oceanographic Institution, Woods Hole, MA

Herndl GJ, Reinthaler T, Teira E, van Aken H, Veth C, Pernthaler A, Pernthaler J (2005) Contribution of Archaea to total prokaryotic production in the deep Atlantic Ocean. Appl Environ Microbiol 71:2303-2309

Huyer A, Smith RL, Fleischbein J (2002) The coastal ocean off Oregon and northern California during the 1997-8 El Niño. Prog Oceanogr 54:311-341

Karner MB, DeLong EF, Karl DM (2001) Archaeal dominance in the mesopelagic zone of the Pacific Ocean. Nature 409: $507-510$

Kruskal JB (1964) Multidimensional scaling by optimizing goodness of fit to a nonmetric hypothesis. Psychometrika 29:1-27

Lee N, Halkjær P, Andreasen KH, Juretschko S, Nielsen JL, Schleifer KH, Wagner M (1999) Combination of fluorescent in situ hybridization and microautoradiographya new tool for structure-function analyses in microbial ecology. Appl Environ Microbiol 65:1289-1297

Long RA, Azam F (2001) Microscale patchiness of bacterioplankton assemblage richness in seawater. Aquat Microb Ecol 26:103-113

Longnecker K, Sherr BF, Sherr EB (2005) Activity and phylogenetic diversity of high and low nucleic acid content, and ETS-active, bacterial cells in an upwelling ecosystem. Appl Environ Microbiol 71:7737-7749

Malmstrom RR, Kiene RP, Cottrell MT, Kirchman DL (2004a) Contribution of SAR11 bacteria to dissolved dimethylsulfoniopropionate and amino acid uptake in the North Atlantic Ocean. Appl Environ Microbiol 70:4129-4135

Malmstrom RR, Kiene RP, Kirchman DL (2004b) Identification and enumeration of bacteria assimilating dimethylsulfoniopropionate (DMSP) in the North Atlantic and Gulf of Mexico. Limnol Oceanogr 49:597-606

Manz W, Amann R, Ludwig W, Wagner M, Schleifer KH (1992) Phylogenetic oligodeoxynucleotide probes for the major subclasses of Proteobacteria: problems and solutions. Syst Appl Microbiol 15:593-600

Manz W, Amann R, Ludwig W, Vancanneyt M, Schleifer KH (1996) Application of a suite of 16S rRNA-specific oligonucleotide probes designed to investigate bacteria of the phylum Cytophaga-Flavobacter-Bacteroides in the natural environment. Microbiology 142:1097-1106

Marie D, Partensky F, Jacquet S, Vaulot D (1997) Enumeration and cell cycle analysis of natural populations of 
marine picoplankton by flow cytometry using the nucleic acid stain SYBR Green I. Appl Environ Microbiol 63: 186-193

Mather PM (1976) Computational methods of multivariate analysis in physical geography. Wiley \& Sons, London

Morris RM, Rappé MS, Connon SA, Vergin KL, Siebold WA, Carlson CA, Giovannoni SJ (2002) SAR11 clade dominates ocean surface bacterioplankton communities. Nature 420: $806-810$

Ouverney CC, Fuhrman JA (1999) Combined microautoradiography-16S rRNA probe technique for determination of radioisotope uptake by specific microbial cell types in situ. Appl Environ Microbiol 65:1746-1752

Ouverney CC, Fuhrman JA (2000) Marine planktonic Archaea take up amino acids. Appl Environ Microbiol 66: 4829-4833

Peterson WT, Keister JE, Feinberg LR (2002) The effects of the 1997-1999 El Niño/La Niña events on the hydrography and zooplankton off the central Oregon coast. Prog Oceanogr 54:381-398

Servais P, Casamayor EO, Courties C, Catala P, Parthuisot N, Lebaron P (2003) Activity and diversity of bacterial cells with high and low nucleic acid content. Aquat Microb Ecol 33:41-51

Seymour JR, Mitchell JG, Pearson L, Waters RL (2000) Heterogeneity in bacterioplankton abundance from 4.5 millimetre resolution sampling. Aquat Microb Ecol 22: 143-153

Seymour JR, Mitchell JG, Seuront L (2004) Microscale heterogeneity in the activity of coastal bacterioplankton communities. Aquat Microb Ecol 35:1-16

Sherr EB, Sherr BF, Cowles TJ (2001) Mesoscale variability in bacterial activity in the Northeast Pacific Ocean off Ore-

Editorial responsibility: Karel Šimek,

České Budějovice, Czech Republic gon, USA. Aquat Microb Ecol 25:21-30

Smith DC, Azam F (1992) A simple, economical method for measuring bacterial protein synthesis rates in sea water using ${ }^{3} \mathrm{H}$-leucine. Mar Microb Food Webs 6:107-114

Stahl DA, Amann R (1991) Development and application of nucleic acid probes. In: Stackebrandt E, Goodfellow M (eds) Nucleic acid techniques in bacterial systematics. Wiley \& Sons, Chichester, p 205-248

Strickland JDH, Parsons TR (eds) (1972) A practical handbook of seawater analysis, Vol 167. Fisheries Research Board of Canada, Ottawa

Teira E, Reinthaler T, Pernthaler A, Pernthaler J, Herndl GJ (2004) Combining catalyzed reporter deposition-fluorescence in situ hybridization and microautoradiography to detect substrate utilization by bacteria and Archaea in the deep ocean. Appl Environ Microbiol 70:4411-4414

Venter JC, Remington K, Heidelberg JF, Halpern AL and 19 others (2004) Environmental genome shotgun sequencing of the Sargasso Sea. Science 304:66-74

Vila M, Simó R, Kiene RP, Pinhassi J, González JM, Moran MA, Pedrós-Alió C (2004) Use of microautoradiography combined with fluorescence in situ hybridization to determine dimethylsulfoniopropionate incorporation by marine bacterioplankton taxa. Appl Environ Microbiol 70: 4648-4657

Wallner G, Amann R, Beisker W (1993) Optimizing fluorescent in situ hybridization with rRNA-targeted oligonucleotide probes for flow cytometric identification of microorganisms. Cytometry 14:136-143

Zubkov MV, Fuchs BM, Tarran GA, Burkill PH, Amann R (2002) Mesoscale distribution of dominant bacterioplankton groups in the northern North Sea in early summer. Aquat Microb Ecol 29:135-144

Submitted: August 17, 2005; Accepted: December 12, 2005 Proofs received from author(s): March 1, 2006 